\section{B A Institute of \\ YK Business Administration \\ 六下 \\ Karachi \\ Leadership and Ideas for Tomorrow}

Business Review

Volume 2 Issue 2 July-December 2007

7-1-2007

\title{
Building national digital infrastructure: A case study of semiconductor complex limited
}

Deepak Kappor

Institute of Management Technology, Ghaziabad, Uttar Pradesh, India

Follow this and additional works at: https://ir.iba.edu.pk/businessreview

Part of the Computer and Systems Architecture Commons, Digital Communications and Networking Commons, and the Technology and Innovation Commons

(c) (i)

This work is licensed under a Creative Commons Attribution 4.0 International License.

\section{Recommended Citation}

Kappor, D. (2007). Building national digital infrastructure: A case study of semiconductor complex limited. Business Review, 2(2), 9-28. Retrieved from https://doi.org/10.54784/1990-6587.1387

This article is brought to you by iRepository for open access under the Creative Commons Attribution 4.0 License and is available at https://ir.iba.edu.pk/businessreview/vol2/iss2/2. For more information, please contact irepository@iba.edu.pk. 


\title{
ARTICLE
}

\section{Building National Digital Infrastructure A Case Study of Semiconductor Complex Limited $^{1}$}

\author{
Deepak Kappor \\ Institute of Management Technology \\ Ghaziabad, Uttar Pradesh, India
}

\begin{abstract}
$\mathrm{T}$ he digital revolution and the rapid technology developments thereafter created a real danger of the modern world getting divided into a new type of 'digital-haves and digital-have not's'. It was feared that developing countries like India may not be able to reap the benefits of the 'information age' because of the ever widening gap in technology and relevant infrastructure. As a strategic step to bridge the growing digital divide between India and the technologically advanced economies, the Government of India (GOI) decided to set up Semiconductor Complex Limited (SCL) in the year 1983 to develop Indian capabilities in the critical technology of microelectronics. The objectives delineated for SCL included design, development and manufacture of Very Large Scale Integrated Circuits (VLSI's) and VLSI based systems and sub-systems; and to create a strong Research and Development (R\&D) base. The operations of SCL are located in the city of Mohali, also known as Sahibzada Ajit Singh (SAS) Nagar, in the State of Punjab on the outskirts of the city of Chandigarh. The present case attempts to critically examine the issues relating to building technological capabilities and digital infrastructure development undertaken at SCL.
\end{abstract}

\section{SIGNIFICANCE OF TECHNOLOGY}

Technology is the practical implementation of knowledge, a means of aiding human endeavor (Khalil, 2000). Zeleny (1986) proposed that any technology consists of several components such as the hardware, the software, brain ware and know-how. Know-how is either learned or acquired. Technical know-how is acquired by receiving formal or informal education or training or by working closely with an expert in a given field of activity. Know-how can also be acquired through a recognized method of technology transfer. This requires time, energy, resources and dedication. Technology related issues also need appropriate management not only by the concerned organizations but also at the level of the national governments. A report of the National Research Council (1987) has defined 'Technology Management' as 'an interdisciplinary field concerned with the planning, development and implementation of technological capabilities to shape and accomplish the operational and strategic objectives of an organization.'

\footnotetext{
${ }^{1} \mathrm{http}: / / \mathrm{www}$. sclindia.com
} 


\section{IC-A CRITICAL COMPONENT IN DIGITAL TECHNOLOGY}

The development of the transistor by John Bardeen, Walter Brattain, and William Shockley in 1948 led to a revolution in electronics. Bardeen, Brattain, and Shockley were awarded the Nobel Prize in Physics in 1956 for this work. By 1960, the transistor had replaced vacuum tube in different electronic applications and had become the basic building block in the design and construction of electronic circuits. An integrated circuit (IC) is a collection of interconnected transistors, diodes, capacitors, and resistors fabricated on a single piece of silicon. The IC was invented independently by Jack Kilby at Texas Instruments in late 1958 and by Robert Noyce at Fairchild Camera and Instruments early in 1959. ICs contain several thousand to several million components in an area as small as one square centimeter.

\section{DESIGN AND MANUFACTURE OF CMOS ICS AT SCL}

CMOS technology is a popular technology that is used globally for the manufacture of ICs. This technology has also been selected and adopted for manufacturing ICs at the SCL. The CMOS technology takes advantage of both the high speed of NMOS circuits and the ease of making of PMOS circuits. CMOS process requires both nchannel (NMOS) and p-channel (PMOS) transistors to be built in the same silicon wafer. To accommodate both $\mathrm{p}$ and $\mathrm{n}$ types of devices, special regions called wells are created in which the semiconductor material is opposite to the type of the channel. A PMOS transistor has to be created in either an n-type substrate or an nwell, while an NMOS device resides in either a p-type substrate or a p-well. A dualwell approach that uses both n-wells and p-wells, grown on top of an epitaxial layer, is used in CMOS process. The detailed design of an IC is first done by the engineers of the 'design division' of SCL. SCL's design center is equipped with SUN SPARC/ULTRA workstations, Mentor Graphics, View-logic and Synopsis Computer Aided Design (CAD) tools.

\section{IC Manufacturing at SCL}

CMOS manufacturing process requires the execution of a sequence of basic operations that are undertaken repetitively in the course of the manufacturing process. SCL has built a state of the art facility that is capable of processing six inch wafers in a CLASS 10 clean room. The facility has been designed by M/S Anderson DeBartolo, USA and is certified by M/S Crowthorne Hi-Tec Services Limited of UK. Associated in-house facilities of Ultra High Purity (UHP) water and nitrogen plants have also been set up. SCL's wafer fabrication facility is suitable for processing wafers using 0.8 micron technology and can be further upgraded to 0.6 micron technological capability. Details of different process technologies available at SCL are given in the Appendix-1. Some of the important operations that are performed at SCL on a silicon wafer for the manufacture of an IC using the CMOS process are given as under: 
a) Silicon Wafer: The base material for the manufacturing process is a singlecrystalline, lightly doped silicon wafer. At present, SCL uses six-inch wafers at its wafer fabrication facility.

b) Photolithography: In photolithography process, the required area on the chip is masked out using the appropriate optical mask so that a desired processing step like acid etching, oxidation etc. can be undertaken. SCL has a set up of advanced photolithography equipment at its manufacturing facility.

c) Diffusion and Ion Implantation: IC manufacturing activity necessitates changing the dopant concentration for some portions of the silicon material. Diffusion and Ion implantation are the two major mechanisms for introducing such dopants. SCL has advanced Centotherm diffusion furnaces, and both medium current and high current ion implanters available at its manufacturing facility. SCL also has a 'Rapid Thermal Annealing System' to enable the removal of the material defects that may arise in the silicon substrate during the course of high energy ion implantation.

d) Deposition: The use of CMOS process for IC manufacturing requires the deposition of different layers on the raw silicon wafer. The layers so deposited act as insulating or conducting layers or as buffers for undertaking another subsequent processing step. SCL has advanced deposition equipment like the Varian's Metal Sputtering System, Novellus Plasma Enhanced Chemical Vapor Deposition (PECVD) System, Titan Chemical Spray processor installed at its manufacturing facility.

e) Etching: Etching is used to form patterns such as wires and contact holes after the deposition of the required material. Wet etching and dry etching are the two methods to undertake the etching process. SCL has dry etch systems, wet etch systems and also a plasma etcher.

f) Packaging of Integrated Circuits: IC packaging provides a means to bring signal and supply wires in and out of the silicon chip and helps remove the heat generated by the electronic circuit. Packaging also provides mechanical support besides protecting the chip from humidity and other harsh environmental conditions. Polymers and ceramics are the commonly used materials for the packaging of ICs. At present, SCL has built capabilities for packaging ceramic devices with a pin count from 8 to 208 in Ceramic Dualin-line Package (CERDIP), Ceramic Quad Package (CERQUAD), and Programmable Gate Array (PGA). The packaging facility is being further augmented by introduction of plastic packaging in Dual-in-line Package (DIP), Plastic Quad Flat Pack (PQFP), Plastic Leaded Chip Carrier Packages (PLCC), and Small Outline Integrated Circuit (SOIC) configurations.

g) Testing of ICs: After getting manufactured, it is necessary to check whether the manufactured IC actually works as per the design. A number of manufacturing defects may arise during fabrication that can have a detrimental effect on an IC's performance. Different tests undertaken on an IC after its manufacturing are: a) diagnostic tests used to identify and locate 
the offending parts of an IC; b) functional tests (go/ no-go) to determine whether or not the manufactured component is functional; c) parametric tests to check nondiscrete parameters like clock frequencies, noise margins under different temperature and supply voltage conditions. SCL uses specialized equipment and software to undertake necessary tests. At present SCL has a Digital VLSI Series-10 Tester (from Schlumberger), an ASIX Tester (from Credence) and a Mixed Signal Tester (STS 300 from Credence) for performing different tests on ICs.

\section{SCL'S STRENGTHS AND WEAKNESSES}

Since its inception in 1983, SCL has established itself as a reputed microelectronics organization manufacturing different products and providing different services (Appendix-2) thereby contributing significantly to the development of indigenous digital infrastructure in India. While SCL has built up strengths in certain areas, it continues to have weaknesses in several other areas. These are discussed in detail as under:

\section{CHIP MANUFACTURING}

\section{Strengths}

Since the CMOS technology for the manufacture of ICs was new in India in the 1980s, SCL started its operations in 1983 through collaboration with American Microsystems Inc (AMI); a United States of America (US) based Semiconductor Company. SCL commenced commercial production using the 5 (Five) micron ${ }^{2}$ CMOS technology transferred to SCL by the AMI. Through in-house intensive R\&D efforts, SCL graduated to the next generation 3 micron, 2 micron, 1.2 micron, 0.8 micron technology. SCL's semiconductor operations offer design, wafer fabrication, testing, packaging, quality assurance and reliability test. The company has successfully developed and manufactured a number of VLSI products for different applications.

\section{Weaknesses}

1) SCL is operating in a very dynamic business domain wherein international firms like Intel come up with an improved technology and products thereof every few years. Gordon E. Moore, co-founder of Intel had made an empirical observation (known as Moore's Law) that the transistor density of integrated circuits with respect to minimum component cost, doubles every twenty-four months. However, SCL has been a 'Technology Follower' at the international level and has never been able to attain the position of a 'Technology Leader'.

${ }^{2}$ One Micron $=1 / 10,00,000$ of a metre. 
2) SCL has not been able to become a market leader in components for consumer products even in the domestic Indian market. There seems to be an excessive dependence on government orders from defense and space sectors rather than on developing competitive advantage in technology based products.

3) SCL was setup in 1983 when India was a highly controlled and regulated economy. SCL enjoyed an envious position wherein it did not have to face any major domestic competitor for several years. Yet, SCL has not capitalized on this advantage to build itself into a position of leadership and dominance.

4) SCL has not been able to generate enough internal revenues to undertake up gradation of its manufacturing capabilities. Such an up gradation is necessary in this high-technology business to match the incremental advancements made by SCL in its technological capabilities. SCL has, however, renewed its manufacturing facility with GOI's grants and assistance once after the accidental fire of 1989. The GOI had approved the rebuilding of the SCL's VLSI fabrication facility at an estimated cost of Rs 332.56 crores.

5) The capacity utilization of SCL's wafer fabrication facility has not been optimal (Appendix-3) due to the absence of a significant number of commercially successful products introduced by SCL so far in the marketplace.

\section{SYSTEMS}

\section{Strengths}

SCL had also setup a separate VLSI based system manufacturing and applications support department known as the 'Systems Division' at its Mohali based chip manufacturing facility. The systems division of SCL has manufactured several products like the electronic watch modules, British Broadcasting Corporation (BBC) Acorn Computer for the Computer Literacy and Studies in Schools (CLASS) program, Three Phase Energy Meters etc.

\section{Weaknesses}

1) The BBC Acorn Computers assembled by SCL, however, did not generate a sustained demand. SCL's system division has not endeavored to produce competitive products using SCL's in-house manufactured $2560 \mathrm{G}^{3}$ microprocessors.

2) SCL's system division has not engaged in directly selling products under the SCL logo that could have enabled SCL to build up its brand name.

\footnotetext{
${ }^{3}$ SCL 2560 G microprocessors are based on technology obtained from Rockwell International, USA
} 


\section{ASICs, ASSPs and SMART Cards}

Strengths

1) SCL offers its customers total solutions by providing Standard / Application Specific Standard Products (ASSPs), designing chips from concepts and creating products around Application Specific Integrated Circuits (ASICs) for industrial segments. Many interesting products like the water purifier ASIC, the smoke detector ASIC have been developed. Design of an ASIC for the Radio Sonde required for the Indian Meteorological Department has also been completed.

2) SCL has also successfully manufactured products like the Smart Cards that have several applications in the present times.

\section{Weaknesses}

1) Even while several ASICs and smart cards have been successfully developed by $\mathrm{SCL}$, adequate efforts do not seem to have been made in their marketing etc.

\section{GALLIUM ARSENIDE FACILITY AT HYDERABAD}

\section{Strengths}

The SCL established as a turnkey project a facility at Hyderabad for the Gallium Arsenide (GaAs) based Monolithic Microwave Integrated Circuits (MMICs) for the Defense Research and Development Organization (DRDO). This facility produced the first MMIC in September 1997. By the year 2004, the production of $12 \mathrm{GHz}$ and $18 \mathrm{GHz}$ MMIC technology including linear and switch processes was successfully implemented at the Gallium Arsenide Enabling Technology Centre (GAETEC). GaAs as a semiconductor material has several advantages over Silicon such as a) higher electron mobility, less noise at high frequencies, higher breakdown voltages; b) can be used to emit light as compared to Silicon that has poor light emitting characteristics; c) higher switching speed. The MMICs find applications in military, space and civilian sectors. GaAs is a critical technology that has traditionally been strongly controlled by the developed countries.

\section{Weaknesses}

1) The GAETEC project has largely fulfilled defense, space and other strategic requirements of India. The possibility of revenue generation by making components for commercial applications based on the GaAs technology has not been extensively explored.

2) The GaAs facility was built using the expertise from SCL but has now been made independent of SCL. This is likely to hamper the utilization of synergy and possible gains thereof between the SCL, Chandigarh and GAETEC, Hyderabad. 


\section{MEMS FACILITY}

\section{Strengths}

1) The SCL has recently entered into the emerging area of Micro Electro Mechanical Systems (MEMS). SCL's wafer fabrication facility has recently been augmented into a state-of-art MEMS foundry. Different MEMS products developed by SCL like the pressure sensors and the temperature sensors seem to have a good market potential.

\section{Weaknesses}

1) SCL does not seem to have put enough efforts in creating and developing a market for the products developed by its MEMS facility.

2) Entry into MEMS may divert SCL's attention from its major objective of attaining leadership in VLSI design and manufacturing technology.

\section{VEDANT PROGRAMME OF SCL}

\section{Strengths}

1) VEDANT (VLSI Design Education and Training) programme covers the complete spectrum of VLSI design training for aspiring engineers. In addition, unique opportunity of design realization on silicon is provided through SCL's India Chip Programme.

2) Special emphasis has recently been given on project based training on high end Electronic Design Automation (EDA) Tools.

3) SCL has also used its VEDANT program to makeup for the depleted internal design manpower and to train engineers of customers like the Vikram Sarabhai Space Center (VSSC), Thiruvanthapuram for facilitating extended design support.

\section{Weaknesses}

1) The beneficial effect of the VEDANT programme on SCL's research activities is debatable given the resources spent by SCL.

\section{INDIA CHIP PROGRAMME}

\section{Strengths}

SCL started the India Chip Programme to fulfill the objective of providing opportunity to IC designers to see their design prototype developed inexpensively. The salient features of the India Chip Programme are: 
1) The India Chip Programme is a programme of 'Multi-Product Wafer Runs' undertaken at regular intervals by SCL. This programme envisages manufacture of different circuits from various designers on a common mask set and silicon wafers thereby reducing the cost of making prototypes per design. IC designers design circuits using SCL's design kit that includes SCL's cell library, design rules, model parameters and generate Graphic Data System (GDS II) data for mask fabrication.

2) Mask fabrication, wafer fabrication and parametric testing of the designed ICs made is also taken up by SCL.

Weaknesses

1) The promotion of creativity of the individual Indian VLSI design engineers, or the efforts of the different academic and research institutions to foster innovation etc. is not likely to be completely realized as the costs involved in IC making are usually beyond the reach of not only the individual researchers but are a difficult proposition even for the academic and research institutions in India without adequate financial support.

2) Though this program is likely to be of some benefit to the existing design firms in India - but most of such design firms do not need any major financial support.

\section{JOINT EDUCATION AND RESEARCH PROGRAMMES}

Strengths

1) SCL offers opportunities for joint research and education with leading education and research institutes of India. For example, SCL has signed a Memorandum of Understanding (MOU) with the Panjab University (PU), Chandigarh for offering a joint program in Master of Technology (M.Tech) in Microelectronics.

2)

Weaknesses

1) Efforts undertaken so far seem to be directed more on teaching rather than on carrying out research in critical areas.

\section{INFORMATION TECHNOLOGY SERVICES}

\section{Strengths}

1) SCL offers information technology services and need based IT solutions for Land Records Management, GIS/GPS Solutions, Smart Card \& Smart Card Based Solutions, Health / Hospital Management Systems, Document Management Systems. 


\section{Weaknesses}

1) Perhaps, SCL should focus on developing capabilities in software that is related to the semiconductor components that it designs and/or manufactures and wherein there is a tremendous potential that can be exploited.

\section{DIGITAL TECHNOLOGY MANAGEMENT AND INTEGRATION AT SCL}

1) According to Ford (1988), five factors determine a company's technology acquisition decision. These are (a) the company's relative standing in technology; (b) the urgency of acquisition; (c) the level of commitment to the acquisition or the level of investment involved; (d) technology position on the life-cycle curve; and (e) the classification of the technology as distinctive, basic, or external. Based on above, different methods that are possible for the acquisition of technology are: (a) using internal R\&D, (b) participating in a joint venture, (c) contracting out for R\&D, (d) licensing of technology, and (e) buying the technology from others. SCL decided to buy 5 micron technology and subsequently develop it further through in-house R\&D inspite of the limited domestic technical capabilities available in 1983. SCL has been successful in absorbing and further developing the technology purchased by it.

2) SCL has developed indigenous design, development, manufacturing and related capabilities for the manufacture of CMOS based ICs. It has also successfully launched and completed a number of technology development projects for commercial as well as strategic applications. These include the development of 3 micron CMOS, Electrically Erasable Programmable Read-only Memory (EEPROM), 2 micron CMOS, Charge-Coupled Device (CCD), and 1.2 micron CMOS technologies and products based on these technologies. But, it is debatable whether SCL has been a commercial success. Much of SCL's revenue is generated as a consequence of the work done for the GOI. This includes the work done for the space and defense sectors, supplying of computers assembled at SCL for the CLASS program, turnkey project for the setting up of GAETEC etc.

3) SCL's is a high technology (high-tech) company. A hi-tech company (Larsen and Rogers, 1988; Mohrman and Von Ginlow, 1990): a) employs highly educated . people; b) Its technology changes at a faster rate than that of other industries; c) It competes with technological innovation; d) It has high levels of research-anddevelopment expenditure; e) It has the potential to use technology for rapid growth. SCL has a highly educated and trained workforce at its design and manufacturing facilities and it continues to be significantly dependent on technology, R\&D and innovation for its success.

4) The technology development activities at SCL have so far been based on the 'brute force technique of miniaturization' that is being followed by the leading 
players like Intel, Advanced Micro Devices (AMD) and others. This involves 'increasing the number density of components on a chip rather than 'reducing the number of components per function'. According to the former Chairman and Managing Director (CMD) of SCL Dr M.J. Zarabi" "I have all along believed that the next breakthrough in microelectronics must come through an altogether new approach that aims at synthesizing electronics functions directly from Physics - the functional approach - without going through conventional circuit theory approach and dealing with traditional circuit elements/components! Evidently, this approach calls for going directly to the nature and exploiting the known as well as yet unknown elegant physical and biomolecular phenomena. And this in my opinion is the direction that Nanotechnology should take." The world is already moving towards the development of molecular structures for realizing digital circuits and for replacing existing processors - and SCL needs to focus here too where the future lies!

\section{MAJOR CHALLENGES FOR SCL}

1) SCL has perhaps not utilized business strategy to help define the business environment in which it operates. As a consequence, it is GOI's policies rather than 'firm strategy' that determine the business actions of SCL. Hamel (1996) distinguishes strategizing from planning by the degree of innovation included in the strategy. He points out that the world has been more hospitable to industry revolutionaries producing strategic innovation rather than to industry incumbents.

2) Development of indigenous raw materials and equipment for undertaking manufacturing activities at SCL has not been adequately promoted during the more than two decades of existence of SCL. SCL is still largely dependent on the developed countries for the supply of raw materials and equipment for its operations. The different raw material and equipment procured from abroad are quite costly. Should SCL collaborate with different local organizations to enable development of indigenous capabilities for manufacturing raw material and equipment used by it?

3) Prior to the initiation of economic reforms in India, it was the ownership of physical assets that determined the value of a company. Success in the postreform period is largely dependent on the quality of the people working for an organization to perform the different tasks. In the high-technology business in which SCL operates, it is technology and people that exercise a major influence on the value of a company. According to Quinn et al. (1996), the intellect of contemporary organizations operates at the four levels of cognitive knowledge or know-what, advanced skills or know-how, system understanding or know-why, self-motivated creativity or care-why.

\footnotetext{
${ }^{4}$ http://www.nanovip.com/directory/Detailed/1267.php
} 
An issue for concern to SCL is that how should SCL focus on achieving self-motivated creativity, or care-why? SCL has also not been very successful in retaining its talented manpower. It needs to be emphasized that these days' talented employees look more for opportunities for career development, training opportunities in their job rather than emphasizing only on monetary compensation.

4) The dominant logic of SCL has shifted between R\&D and production over the time period of its more than two decades of existence. It is debatable whether SCL should pursue R\&D oriented production or productionoriented R\&D. Should SCL managers use technology as a part of the larger business system and as a competitive weapon? Research conducted by Frohman (1982) reveals the commonalities among companies that use technology as a competitive weapon: i) Management views technology as a major competitive weapon but does not emphasize it at the expense of other areas; ii) The criteria used to support any project consist of (a) whether the project supports the business goal, (b) whether the project protects and/or establishes technological leadership, and (c) whether the project solves customer problems. SCL has to decide on how to use technology development as a competitive weapon in its business!

5) Heim and Compton (1992) reported that "most efforts to develop a discipline of manufacturing have concentrated on understanding the performance of unit operations and activities, in the belief that maximizing the effectiveness of separate parts would result in an optimized system". Such an approach to systems optimization neglects the interactions and dependencies of the components and processes in complex manufacturing systems. SCL needs to decide whether it should give still more attention to management and coordination related issues!

6) SCL has not been able to produce competitive commercial semiconductor products required by India's rapidly growing electronics industry-whether in medical electronics, telecommunications, industrial office automation, consumer electronics etc. According to Professor R.V. Raja Kumar ${ }^{5}$," The Semiconductor Complex Limited, Chandigarh is a low density fabrication facility catering to a small section of our market. The GaAs facility in Hyderabad has been catering mainly to defense applications. Most of the electronic components in the form of ICs come from outside the country." India's total semiconductor consumption has grown significantly in the recent years. In 2005 , it was about US $\$ 2.8$ billion, met chiefly through imports. This demand is likely to exceed US $\$ 36$ billion by the year 2015 . There is a worry in some quarters that if India's domestic manufacturing output of semiconductors is not increased, India would have to import over

${ }^{5} \mathrm{http}: / /$ economictimes.indiatimes.com/articleshowicicinri/msid-1933470,curpg$3 . \mathrm{cms}$ 
\$150 billion worth of semiconductors during the next 10 years. International level companies are now planning to enter India to fill this gap in the domestic supply. Would SCL continue to be competitive in the face of competition from such international IC firms?

7) Major MNCs engaged in VLSI design have already entered India in a big way. Texas Instruments was the first MNC to set up design operations in India in 1985. All the global top ten fabless design companies have now set up their India operations. Nineteen of the top twenty-five semiconductor companies are already in India engaged in design operations. Perhaps, more than 130 semiconductor design houses are now developing 'Intellectual Property' in India not only for MNCs but also for venture capital backed new companies in the Silicon Valley. On the other hand, SCL's initiative of setting up SCL design centers in different Indian cities has not been very successful in achieving the desired objectives.

8) SCL's financial performance ${ }^{6}$ has been dismal, particularly in the recent years (Appendix-4). The sales turnover of SCL during 2005-2006 was Rs 26.41 crore as against Rs 30.78 crore in the previous financial year. The net loss for 2005-2006 was Rs 15.53 crore against the loss of Rs 42.14 crore in the previous year. The company has accumulated losses of Rs. 147.92 crores at the end of the financial year 2005-2006. The accumulated losses are more than $50 \%$ of its net worth, which makes SCL a potentially sick unit under Section-23 of the Sick Industrial Companies [Special Provisions] Act, 1985.

\section{POSSIBLE RESPONSE OF SCL TO CHALLENGES}

1) As technologies mature, they become known as base technologies. They are essential for participation in business, but provide a firm with little or no competitive advantage (Arthur D. Little, 1981, 1983). Base technologies are considered commodities usually available to all competitors. It is necessary, therefore, for SCL to strive to move quickly up on the technology front and provide challenge to the global players. SCL has recently sought proposals through a Global Tender for up gradation of its facility to $0.35 / 0.25$ micron or better capability - and these proposals are being currently evaluated. The difficulty, perhaps, would arise in arranging necessary financial resources!

2) Since GOI is the principal buyer of SCL's products for the defense and space applications, SCL should identify the principal buyer's requirements for the present and estimate likely requirements in future. SCL's R\&D should then try to focus more on the 'forecast needs'! Jain and Triandis (1990) proposed the following R\&D needs that apply to any company's technology portfolio: a) Normative needs: wherein the research is directed toward satisfying the needs of the user, the user being the primary or

${ }^{6} 28^{\text {th }}$ Annual Report 2005-2006 of Semiconductor Complex Limited (SCL) 
follow-on beneficiary of the research project; b) Comparative needs: where the research is driven by the need to stay in the race with competitors; c) Forecast needs: where research is driven by the forecast of future changes in technology, products, consumer behavior, or new regulations.

3) SCL needs to carefully identify its core competences and concentrate on different businesses based on such an identification of its competences. SCL must clearly identify what it does best, what it can do that no other company can do better, and what will permit it to achieve the best-of-the world status in regard to what it does. It should then develop its plans accordingly. SCL also needs to build market interface capabilities particularly with regard to selling and achieving customer satisfaction. SCL should also develop internal mechanisms for ensuring necessary training for its employees.

4) SCL needs to devise innovative measures to attract engineering and management talent at entry levels as also at middle and top levels through lateral entry, wherever necessary. For this, SCL needs to devise a mechanism to constantly examine the potential candidates.

5) SCL, through appropriate assistance from the GOI, may examine the possibility of developing a cluster of microelectronics industry in Mohali that could enable SCL to become a 'focal business'. According to Lee and Reid (1991), the comparative strength of a nation's technical expertise depends among other things on the support extended by the government to R\&D activities and to collaboration between industries, universities and government. Both the GOI and SCL need to take appropriate steps to promote such collaboration in a way that it meets the test of the marketplace and the needs of the customers. The rise of entrepreneurship in the Silicon Valley in the late 1970s and early 1980s is an illustration of the process of building up entrepreneurship, creativity and innovation and using these factors for the growth of high technology. Frederick Terman, engineering Professor and Dean at Stanford University who was the brain behind the Silicon Valley, had not only understood the value of technology but also the necessity of exploiting the technology commercially!

6) SCL needs to promote close coordination and synergy between its different internal departments to remain competitive. Potter (1990) has described three ways of managing technical projects using sports analogies introduced by Lorenz (1987). The approaches suggested for product development are (a) sequential, (b) iterative loop, and (c) team approaches. Team based approaches can be used to improve efficiency, to reduce the time to bring the products to the market, to be responsive to customer needs and to eliminate any impediments to the progress of SCL's technical projects.

7) Hammer and Champy (1993) have argued that in order to succeed in today's business environment of high competition, rapid technological change, companies cannot rely only on incremental improvements but should engage in radical change, or "discontinuous thinking". A company 
should be ready to challenge and possibly abandon fundamental assumptions about how it does its work. SCL can use the concept of reengineering to look beyond tasks, jobs, and organizational structure so that SCL can instead focus on its processes.

Has SCL already achieved the strategic objectives for which it was set up by the GOI? What should be the future role of SCL from the perspective of the GOI? Should its role be confined to being a research laboratory of the GOI? These are some of the questions that necessitate appropriate answers. The GOI has recently changed the nomenclature of SCL from Semiconductor Complex Limited to Semiconductor Laboratory. The administrative control of SCL has been transferred to the Department of Space, GOI from the Ministry of Information Technology (MIT), GOI vide Presidential Notification No. CD-120/2005 dated 1.3.2005? Some people are skeptical whether this was a correct decision? SCL has to explore and examine the different options available to it.

\section{APPENDIX-1}

Table 1: Available Process Technologies at SCL

\begin{tabular}{|c|c|c|c|c|c|c|}
\hline \multicolumn{7}{|c|}{ AVAILABLE PROCESS TECHNOLOGIES } \\
\hline $\begin{array}{l}\text { Process } \\
\text { Family }\end{array}$ & Name & $\begin{array}{l}\text { Well } \\
\text { Type }\end{array}$ & $\begin{array}{l}\text { Poly/ } \\
\text { Metal } \\
\text { Layers }\end{array}$ & $\begin{array}{l}\text { Operating } \\
\text { Voltage } \\
\text { (Volts) }\end{array}$ & $\begin{array}{l}\text { Prop } \\
\text { Delay } \\
(\mathrm{ns})\end{array}$ & Remarks \\
\hline \multirow{6}{*}{$\begin{array}{ll}\text { CMOS } & 3 \\
\text { MICRON }\end{array}$} & $\mathrm{C} 3 \mathrm{~A}$ & $\mathrm{P}$ & IP/IM & 5.0 & 0.9 & DIGITAL \\
\hline & C3B & $P$ & $2 \mathrm{P} / 1 \mathrm{M}$ & 5.0 & 0.9 & ANALOG \\
\hline & C3D & $P$ & $\mathrm{IP} / 2 \mathrm{M}$ & 5.0 & 0.9 & DIGITAL \\
\hline & $\mathrm{C} 3 \mathrm{H}$ & $P$ & $2 \mathrm{P} / 1 \mathrm{M}$ & 12.0 & 1.5 & 12V ANALOG \\
\hline & $\mathrm{C} 3 \mathrm{M}$ & $P$ & $1 \mathrm{P} / 1 \mathrm{M}$ & 1.5 & 0.9 & $\begin{array}{ll}1.5 \mathrm{~V} & \text { MICROPOWER } \\
\text { APPLICATION } & \end{array}$ \\
\hline & $\mathrm{C} 3 \mathrm{~N}$ & $\mathrm{~N}$ & $1 \mathrm{P} / 1 \mathrm{M}$ & 5.0 & 0.8 & HIGH SPEED DIGITAL \\
\hline $\begin{array}{ll}\text { CMOS } & 2 \\
\text { MICRON }\end{array}$ & $\begin{array}{l}\mathrm{C} 2 \mathrm{~A} \\
\mathrm{C} 2 \mathrm{D} \\
\mathrm{C} 2 \mathrm{~B}\end{array}$ & $\begin{array}{l}T \\
T \\
T\end{array}$ & $\begin{array}{l}1 \mathrm{P} / 1 \mathrm{M} \\
1 \mathrm{P} / 2 \mathrm{M} \\
2 \mathrm{P} / 1 \mathrm{M}\end{array}$ & $\begin{array}{l}5.0 \\
5.0 \\
5.0\end{array}$ & $\begin{array}{l}0.4 \\
0.4 \\
0.4\end{array}$ & DIGITAL/MIXED SIGNAL \\
\hline $\begin{array}{ll}\text { CMOS } & 1.2 \\
\text { MICRON }\end{array}$ & $\begin{array}{l}\text { C1A } \\
\text { C1D } \\
\text { C1M }\end{array}$ & $\begin{array}{l}T \\
T \\
T\end{array}$ & $\begin{array}{l}1 \mathrm{P} / 1 \mathrm{M} \\
1 \mathrm{P} / 2 \mathrm{M} \\
1 \mathrm{P} / 1 \mathrm{M}\end{array}$ & $\begin{array}{l}5.0 \\
5.0 \\
1.5\end{array}$ & $\begin{array}{l}0.2 \\
0.2 \\
0.2\end{array}$ & $\begin{array}{lr}\text { DIGITALMIXED } & \text { SIGNAL } \\
\text { SALICIDE } & \\
\text { OPTION } & \\
1.5 \mathrm{~V} & \text { MICROPOWER } \\
\text { APPLICATION } & \\
\end{array}$ \\
\hline $\begin{array}{l}\text { CMOS } 0.8 \\
\text { MICRON }\end{array}$ & $\begin{array}{l}\text { CP8D } \\
\text { CP8S } \\
\text { CP8B }\end{array}$ & $\begin{array}{l}\mathrm{T} \\
\mathrm{T} \\
\mathrm{T}\end{array}$ & $\begin{array}{l}1 \mathrm{P} / 2 \mathrm{M} \\
2 \mathrm{P} / 2 \mathrm{M} \\
2 \mathrm{P} / 1 \mathrm{M}\end{array}$ & $\begin{array}{l}5.0 \\
5.0 \\
5.0\end{array}$ & $\begin{array}{l}0.1 \\
0.1 \\
0.1\end{array}$ & $\begin{array}{l}\text { DIGITAL / MIXED } \\
\text { SALICIDE } \\
\text { OPTION }\end{array}$ \\
\hline BHCMOS-I & $\mathrm{C} 1 \mathrm{H}$ & $T$ & $2 \mathrm{P} / 1 \mathrm{M}$ & $5.0 / 30$ & 0.2 & $\begin{array}{l}\text { HIGH VOLTAGE CMOS WITH } \\
\text { VERTICAL AND LATERAL } \\
\text { BIPOLAR TRANSISTORS }\end{array}$ \\
\hline EEPROM & $\mathrm{C} 2 \mathrm{E}$ & $\mathrm{N}$ & $2 \mathrm{P} / 1 \mathrm{M}$ & $5.0 / 18$ & 0.9 & NON-VOLATILE MEMORY \\
\hline $\mathrm{CCD}$ & NSA & - & $2 \mathrm{P} / 2 \mathrm{M}$ & 15 & - & IR\&VISIBLE IMAGER \\
\hline
\end{tabular}

Source: http://www.sclindia.com 


\section{APPENDIX-2}

Table 2: SCL's Products

\section{1) Standard VLSI Products}

- Tone Pulse Switchable Dialer

- Single Chip Telephone IC

- Single Chip Codec with filter

- DTL Mux

- Analog Watch

- Multifunction Digital Clock with Timer

- Time Slot Zero Transmitter

- Time Slot Zero Receiver

- Hearing Aid IC

2) ASICs and ASSPs

- Programmable Signal Processor (PSP-1)

- Programmable Timer

- Water Purifier ASIC

- Smoke Detection ASIC

- Signal Processing Card ASIC

- Conference Card ASIC

- Pulse Code Modulator (PCM) Encoder

- Infinite Impulse Response (IIR) Filter

- Direct Memory Access Controller (DMAC)

- Hearing Aid ASIC

- Line Card ASIC

- STD PCO ASIC

- RADIO SONDE ASIC

- Multiplexed Analog Signal Processor (MANAS)

- GIST-II (Graphical and Intelligence based Scripting Technology)

- $\quad$ ROIC (Readout Integrated Circuit)

3) MEMS

- Pressure Sensors

(Range: a) 0-10 Bar; b) 0-1 Bar)

- Temperature Sensors

(Range: $-90 \mathrm{C}$ to $55 \mathrm{C}$ ) 


\section{4) SYSTEMS}

- Electronic Circuit Blocks for Clocks

- Unicorn Microcomputers

- Electronic Check Signaling System

- Water Purification System Control Card

- Mini Electronic Exchange

- Digital Pair Gain System

- Electronic Energy Meter, 1 Phase

- Electronic Energy Meter, 3 Phase

- STM-1 systems for BSNL

- 3 Phase Feature Meter with Super cap solution for Power-off condition.

Source: http://www.sclindia.com

\section{APPENDIX-3}

Table 3: Installed Capacity and Actual production at SCL

(Quantity in thousands)

\begin{tabular}{|l|l|l|l|}
\hline & & Installed Capacity & Actual Production \\
\hline 1) & $\begin{array}{l}\text { LSI/VLSI W" } \\
\text { processing }\end{array}$ & 20 & 1.06 \\
\hline 2) & Chip on Board (COB) / ECB & 2500 & 360.00 \\
\hline 3$)$ & $\begin{array}{l}\text { Board Level Assembly / Sub } \\
\text { Systems* }\end{array}$ & 200 & 50.51 \\
\hline 4) & VLSI Packaging** & 1000 & 422.31 \\
\hline \multicolumn{2}{|l}{ Source: 28 } & Annual Report (2005-2006) of Semiconductor Complex Limited \\
\hline
\end{tabular}

* The production of board level assembly /sub systems carried out with the help of Sub-contractors.

** The production of devices includes plastic packaging, carried out with the help of sub contractors. 


\section{Appendix-4}

Table 4A: Profit and Loss Account of SCL for the Year Ended 31 ${ }^{\text {st }}$ March, 2006

\begin{tabular}{|l|l|l|}
\hline Particulars & Year Ended & Year Ended \\
& $31 / 3 / 2006$ & $31 / 3 / 2005$ \\
\hline Income & & \\
Sales (including agency sales) & 174880 & 166006 \\
Less: Excise Duty & 10921 & 11566 \\
Net Sales & 163959 & 154440 \\
Income from Services/Assembly Job & 100169 & 86239 \\
Revenue from NPSM Services & 0 & 67145 \\
Revenue Grant & 165000 & 0 \\
Other Revenue & 35818 & 48973 \\
Capital Grants Trf. From Special Reserve & 63854 & 64421 \\
Accretion to WIP/Finished Goods & 11162 & -228 \\
Net Income & 539962 & 420990 \\
\hline Expenditure & & \\
Raw Material Consumed & 54357 & 65764 \\
Stores \& Spares Consumed & 10622 & 9347 \\
Purchase of Finished Products & 107650 & 146112 \\
Foundry \& Assembly Charges & 11432 & 3448 \\
Employees Remuneration \& Benefits & 157492 & 169442 \\
Power \& Fuel & 64398 & 59786 \\
Repair \& Maintenance & 12523 & 14298 \\
Administrative, selling \& other overheads & 26923 & 31595 \\
Expenditure on IT services & 13749 & 13336 \\
Finance Expense-Interest & 8513 & 1741 \\
Provision and Write Offs & 5034 & 4491 \\
Depreciation & 219727 & 210686 \\
Total Expenditure & 692420 & 730046 \\
Less: Profit for the year & -152458 & -309056 \\
Net Expenditure & 539962 & 420990 \\
\hline Profit for the year & -152458 & -309056 \\
\hline Add: Prior Period Adjustment [Net] & -2849 & -112375 \\
\hline Profit before tax & -155307 & -421431 \\
\hline Profit after tax & -155307 & -421431 \\
\hline Balance of profit b/f from last year & -1323930 & -902499 \\
\hline Balance of profit c/f to Balance Sheet & -1479237 & -1323930 \\
\hline Earnings per Share - Basic \& Diluted (in & -82.43 & -223.67 \\
Rupees) & & \\
\hline As per Our report of even & \\
\hline
\end{tabular}

As per our report of even date attached

For A.K. Sood \& Associates 
Chartered Accountants
A.K. Sood
K. Nagachenchaiah
M.M. Sobti
Partner
Director
Director
Chandigarh
G.L. Sehgal
Vivek Trehan
Dated: 26.07.2006
Head (Finance)
Company Secretary

Source: http://www.sclindia.com

Table 4B: Balance Sheet Abstract and the Company's General Profile

\begin{tabular}{|l|l|}
\hline Registration Details & 3798 \\
\hline Registration Number & 16 \\
State Code & 31.03 .2006 \\
Balance Sheet Date & \\
\hline Capital Raised During the Period & - \\
\hline Public Issue & - \\
Rights Issue & - \\
Bonus Issue & \\
\hline Position of Mobilization and Development of Funds & 1808508 \\
\hline Total Liabilities and Shareholder's funds & 1808508 \\
Total Assets & \\
\hline Sources of Funds & 1884150 \\
\hline Paid-up Capital & 1296824 \\
Reserves and Surplus & 106771 \\
Secured Loans & 223226 \\
Current Liabilities \& Provisions & \\
\hline Application of Funds & 525734 \\
\hline Net Fixed Assets (including Capital work-in-progress) & - \\
Investments & 1506000 \\
Current Assets & - \\
\hline Miscellaneous Expenditure & \\
\hline Performance of the Company & 464946 \\
\hline Turnover including other revenue \& revenue grants & 620253 \\
Total Expenditure including Prior period Adj. & $(-) 155307$ \\
Profit before tax & $(-) 155307$ \\
Profit after tax & $(-) 82.43$ \\
Earnings per share in Rs. & Nil \\
Dividend rate \% & \\
\hline Generic Names of four principal products of the & Description \\
\hline company & SP Card \\
\hline AS PER MONETARY TERMS) & \\
Product Code & \\
\hline
\end{tabular}




\begin{tabular}{|l|l|}
\hline HDC 0823 & Energy Meter \\
HMP 0415 & Codec Devices \\
HAD 2340 & Manas \\
HDC 0959 & \\
\hline
\end{tabular}

As per our report of even date attached

For A.K. Sood \& Associates

Chartered Accountants
A.K. Sood
K. Nagachenchaiah
M.M. Sobti
Partner
Director
Director
Chandigarh
G.L. Sehgal
Vivek Trehan
Dated: 26.07.2006
Head (Finance)
Company Secretary

Source: http://www.sclindia.com

\section{REFERENCES}

Ford, David (1988),'Develop Your Technology Strategy", Long Range Planning, Vol. 21, No. 5, October, pp. 85-94.

Frohman, Alan L. (1982),'Technology as a Competitive Weapon", Harvard Business Review, January-February, pp. 97-104.

Hamel, Gary (1996),'Strategy as Revolution", Harvard Business Review, JulyAugust, pp. 69-82.

Hammer, Michael, \& Champy, James (1993),"Reengineering the Corporation", Harper Business, New York.

Heim, Joseph A., \& Compton, W. Dale (1992),"Operating Principles of World-Class Manufacturing Organizations", In Khalil, T., \& Bayraktar, B. (eds), Management of Technology III, pp. 765-776, Engineering and Management Press, Atlanta/Norcross, GA.

Jain, R.K., \& Triandis, H.C. (1990),'Management of R\&D Organizations", Wiley Interscience, New York.

Khalil, Tarek M. (2000),'Management of Technology-The Key to Competitiveness and Wealth Creation", McGraw-Hill Book Co, Singapore.

Larsen, J., Rogers, E. (1988), 'Silicone Valley: The Rise and Falling of Entrepreneurial Fever, Chapter 7 in Smilor, R., Kozmetsky, G., and Gibson, D. (eds). Creating the Technopolis: Linking Technology Commercialization and Economic development, Ballinger, Cambridge, MA.

Lee, Thomas H., \& Reid, Proctor P. (1991),'National Interests in an Age of Global Technology", National Academy of Engineering, Washington, DC. 
Little, Arthur D. (1981),'Strategic Management of Technology", European Management Forum, Davos.

Little, Arthur D. (1983),'Maturing Chemical Business: An Approach to Renewal", Arthur D. Little Report No. 831001, Oct., Cambridge, MA.

Lorenz, Cristopher (1987)," Scrum and Scrabble-The Japanese Style", Financial Times, June 19.

Mohrman, Susan A., \& Von Glinow, Mary Ann. (1990),"Beyond the Clash: Managing High Technology Professionals", In Von Glinov, M., and Mohrman,. S. (eds.), Managing Complexity in High Technology Organizations, pp. 3-14, Oxford University Press.

National Research Council (1987),'Management of Technology: The Hidden Competitive Advantage, National Academy Press, Washington DC, Report No. CETS-CROSS-6.

Potter, S. (1990),'’Successfully Managing Research, Design and Development", In Khalil, T., \& Bayraktar, B. (eds.), Management of Technology II, Industrial Engineering and Management Press, Atlanta/ Norcross, GA.

Quinn, J.B., Anderson, P., and Finklestein, S. (1996),'Managing Professional Intellect: Making the Most of the Best", Harvard Business Review, March-April.

Zeleny, M. (1986),'High Technology Management", Human Systems Management, Vol. 6, pp. 109-120.

\section{The Educated Person}

"If the feudal Knight was the clearest embodiment of society in the early Middle Ages, and the 'bourgeois' under Capitalism, the educated person will represent Society in the post - capitalist society in which knowledge has become the central resource."

Drucker : Post Capitalist Society, 1993 